\title{
The European Grouping of Territorial Cooperation (EGTC): Towards a Supraregional Scale of Governance in the Greater Region SaarLorLux?
}

\section{Estelle Evrard}

To cite this article: Estelle Evrard (2016): The European Grouping of Territorial Cooperation (EGTC): Towards a Supraregional Scale of Governance in the Greater Region SaarLorLux?, Geopolitics, DOI: $\underline{10.1080 / 14650045.2015 .1104667}$

To link to this article: http://dx.doi.org/10.1080/14650045.2015.1104667

Published online: 25 Feb 2016.

Submit your article to this journal $\square$

Q View related articles 5

View Crossmark data ¿ 


\title{
The European Grouping of Territorial Cooperation (EGTC): Towards a Supraregional Scale of Governance in the Greater Region SaarLorLux?
}

\author{
Estelle Evrard \\ Institute of Geography and Spatial Planning, University of Luxembourg, Esch-sur-Alzette, Luxembourg
}

\begin{abstract}
All over Europe, EGTCs (European Grouping for Territorial Cooperation) are mushrooming. Between 2006, when the EU regulation entered into force, and 2014, 51 EGTCs have been established. Conceived as a legal tool to facilitate cross-border, interregional or transnational cooperation, the EGTC was established after years of lobbying from cross-border organisations. Apart from practical guidelines mostly dedicated to the legal possibilities and limitations of this tool, few academic studies examine the significance of this tool for cross-border governance as such. This paper develops such a perspective, using the case study of the Greater Region SaarLorLux, (Lorraine, Luxembourg, Rhineland-Palatinate, Saarland and Wallonia), where two existing EGTCs are operating. The EGTC INTERREG IV A Greater Region is the only EGTC managing an EU programme; the EGTC Secretariat of the Summit supports the main political organisation in this area. This contribution argues that the EGTC tool can facilitate the emergence of a supraregional scale of governance. This paper examines how this instrument allows the institutionalisation of a cross-border entity in terms of its capacity to embody and perpetuate the cross-border region, and to implement its strategy. It then applies this conceptualisation to the specific context of the Greater Region. The empirical analysis shows that although the two EGTCs institutionalise the cooperation, they are rather conceived as administrative and operational tools. The paper concludes with possible explanations of such a mismatch between the potential of this tool and the effective use of it.
\end{abstract}

\section{Setting the Scene}

Since the 1970s and even more intensively since the 1990s, cross-border areas have institutionalised their cooperation; the Euroregion is the most iconic institutional setting of this wave. ${ }^{1}$ This trend is intrinsically linked to growing functional interdependencies ${ }^{2}$ and the multi-level governance setting structuring the EU regional policy. ${ }^{3}$ Scholars agree that despite the EU integration process, cross-border cooperation areas are "far from being regions in the

CONTACT Estelle Evrard estelle.evrard@uni.lu 0 Institute of Geography and Spatial Planning, University of Luxembourg, Maison des Sciences Humaines (E02-N203), 11, Porte des Sciences, L-4366, Esch-Belval. 
juridico-political sense". They "do not appear particularly successful in constituting new, transnational scales of governance". ${ }^{5}$ Two main reasons hinder their capacity to act as a whole. ${ }^{6}$ First, their organisation as transnational policy networks does not support the establishment of a common capacity. ${ }^{7}$ Actors consequently remain oriented towards their own region, ${ }^{8}$ having difficulties in conceiving and coordinating a common development strategy. ${ }^{9}$ Second, cross-border areas face the challenge of political legitimacy: they are not governed through territorially based popular representation ${ }^{10}$ and have difficulties in effectively reaching "the minds and hearts of 'ordinary people"." ${ }^{11}$

"In order to overcome the obstacles hindering territorial cooperation", the EU instituted a legal tool "for the creation of cooperative groupings in Community territory". ${ }^{12}$ Since then, European Groupings of Territorial Cooperation (EGTC) have mushroomed all over Europe; 51 are currently operating. ${ }^{13}$ Despite several unclarified aspects, lawyers have emphasised the uniqueness of this instrument. ${ }^{14}$ First, the EGTC is the only EU instrument with legal capacity aiming especially at facilitating territorial cooperation. ${ }^{15}$ In comparison, Euroregion is a fuzzy type of cooperation since it does not benefit from a unified status established by the $\mathrm{EU}$ or other international organisations. ${ }^{16}$ When a Euroregion is institutionalised with legal capacity (usually through an association), this legal status remains regulated under national law, thus hindering its cross-border action. ${ }^{17}$ With its legal capacity, the EGTC can sign contracts, establish its own budget, recruit staff and implement projects on behalf of its members. Second, in contrast to the legal frameworks developed under the auspices of the Council of Europe, sub-state authorities as well as nation-states can be members of an EGTC. ${ }^{18}$ This possibility is crucial for cross-border cooperation areas involving small states without a regional level of governance (e.g., Luxembourg). ${ }^{19}$ Third, the EGTC's ultimate goal is intended to support territorial cooperation, either with or without implementing EU projects and programmes. ${ }^{20}$ In addition to these legal analyses, a number of practical handbooks have been published for practitioners. ${ }^{21}$ Some academic studies have analysed the EGTC under the lens of the multi-level governance paradigm, ${ }^{22}$ emphasising how this tool empowers cross-border regions "to circumvent/supersede the national level through a process of negotiation and 'alliances". 23

The aim of this contribution is to focus on cross-border governance, investigating whether this instrument facilitates the emergence of a "new, transnational scale of governance" and thus changes the picture presented earlier. ${ }^{24}$ If the EGTC does not have an impact on the political legitimacy of cross-border cooperation, it provides a legal framework that creates a cross-border legal entity. ${ }^{25}$ The EGTC is capable of embodying and implementing tasks on behalf of its members. ${ }^{26}$ Against this backdrop, we question not only how the EGTC is used as a legal tool, but first and foremost how this new room for manoeuvre is 
interpreted and used by actors in their cross-border strategies of power bargaining. What does this mean for the construction of cross-border regions?

This analysis is anchored within a two-step reflection. First, we conceptualise the emergence of a capacity embodying the whole cross-border cooperation as a process contributing to the institutionalisation of a region. 'Region' is understood as "a process which, once established, is continually reproduced and gradually transformed in individual and institutional practices". ${ }^{27}$ Four interacting stages institutionalise the region: "1) assumption of territorial shape, 2) development of conceptual (symbolic) shape, 3) development of institutions, and 4) establishment as part of the regional system and regional consciousness of the society concerned". ${ }^{28}$ Without claiming a direct affiliation with this conceptualisation, an extensive body of literature has investigated, albeit in a rather differentiated manner, how these different stages contribute to shaping cross-border regions. Scholars have analysed how cross-border actors spatially delimit 'their' cooperation area, ${ }^{29}$ thus providing a general understanding of the institutional mechanisms underpinning the definition of cross-border territorial shapes. Bordering processes initiated in cross-border spaces remain on the research agenda. ${ }^{30}$ In the same vein, numerous institutional analyses have extensively listed the existing cross-border institutions, ${ }^{31}$ providing information on both the conceptual shape and the development of institutions in European crossborder spaces. As to the 'conceptual shape', scholars have demonstrated the ambivalence of the border as a vehicle for both identity and territorial marketing. ${ }^{32}$ Cross-border institutions have also been analysed from a legal point of view, ${ }^{33}$ as well as from a political science and geographical point of view. ${ }^{34}$ Some studies have also analysed the process through which crossborder regions are perpetuated in time and space, investigating in particular their interaction with 'their' citizens. With this contribution, we aim to demonstrate how institutions play a crucial role in embedding and perpetuating the region in the cross-border context. Most institutional settings (e.g., Euroregions) provide an interregional framework and "rules of the game" for the cooperation between cross-border actors. They institutionalise a platform framing the negotiation between institutional partners and the emergence of a common position. The effective implementing powers for common projects rely on the institutional partners, thus hampering the emergence of the region as a whole. The EGTC represents the first EU instrument, which on the one hand allows the institutionalisation of a cross-border common institution that is legally recognised by the EU and member states' laws ${ }^{35}$ and on the other hand confers implementing powers on such an entity. It thus contributes towards embedding the construction of the region in one common independent institution, implementing a common vision and strategy. In this sense, this institution can support and perpetuate the conceptual and territorial shapes of the cross-border region in construction. 
Second, we conceptualise the progressive emergence of a cross-border capacity to construct and perpetuate the region as a 'supraregionalisation process'. We follow Häkli in thinking that "the established levels of authority [the local, the regional and the international] have all emerged interdependently as part of the territorial governmental order in modern societies". ${ }^{36}$ Consequently, "transnational scales ... are produced and reproduced in processes that set alternative perimeters to networks of co-operation between actors who seek strategic advantage from this co-operation". ${ }^{37}$ Cross-border cooperation results from the complex interrelation of European integration and the "hollowing-out" of certain functions of the nation-states. ${ }^{38}$

Accordingly, this contribution first conceptualises the significance of supraregional cooperation and analyses the extent to which the EGTC can be analysed as a tool supporting the emergence of such cooperation. This analytical framework is then set against the tasks and roles conferred on two EGTCs currently operating in the cross-border area of the Greater Region SaarLorLux, which comprises Lorraine, Luxembourg, Rhineland-Palatinate, Saarland and Wallonia. The EGTC managing authority for the INTERREG IV A Greater Region programme - the only one of this kind in the EU - was established in 2010 and was given rather technical functions. The EGTC Secretariat of the Summit of the Executives, created in 2013, is directly involved in the political cross-border cooperation, since it institutionalises the highest political institution of this area, which has existed since 1995. We underline the fact that both EGTCs are given rather technical and operational tasks, leaving the power to structure and implement the cooperation at the regional level. We conclude with possible explanations for such a mismatch between the potential of this tool and the effective use of it.

\section{Conceptualising the Supraregional Institution}

Before providing a definition of the supraregional institution, we suggest going back to some crucial specificities that explain the current prevalence of interregional cross-border cooperation.

A cross-border cooperation area is "a territorial unit that comprises contiguous sub-national units from two or more nation-states". ${ }^{39}$ Yet, according to international law, the ability to interact across borders is limited to nationstates. ${ }^{40}$ Lawyers commonly agree that sub-state authorities from different member states can cooperate within the extent of their competences. ${ }^{41}$ This has two major implications, the first relating to law and the second to political science. Since sub-state units can cooperate only within their respective set of competences, the extent of the cooperation is circumscribed to the sum of competences that the institutions involved have in common ("the lowest common denominator" ${ }^{42}$ ). In this context, depending on each country's constitutional setting, the institutions involved have asymmetric 
competences ("multi-level mismatch"43). In federal countries, federated states have a wide range of competences (e.g., German Länder, Swiss cantons) while sub-state authorities have, in (de)centralised states, limited sets of competences. The nation-state or its representatives' authorities (e.g., French prefecture) are therefore involved in the cross-border cooperation, thus increasing the number of possible partners and blurring the map of competences. This institutional mismatch has been depicted as one of the most obstructive barriers to cross-border cooperation. ${ }^{44}$

The other side of the coin relates to political science. Because no legal order provides an a priori definition of the legal relationships between substate authorities, these face an "institutional ambiguity" ${ }^{45}$ In such a context, actors determine their own sets of rules and the political process consists in negotiating them. ${ }^{46}$ Cross-border cooperation can accordingly be portrayed as a "kleine Außenpolitik" ['mini foreign policy'] ${ }^{47}$; it is a form of noncodified foreign policy. Sub-state authorities progressively negotiate and define common "rules of the game", 48 outlining the extent, the purpose and the routine of their cooperation. Logically, sub-state authorities associated in a cross-border context ensure that they are equally represented and associated within the entire decision-making process ('interregional cooperation'), from the political decision down to its operational implementation in each (sub)-state authority. (Sub)-state units engage in such cooperation following common good will, which de facto fluctuates over time. The effective implementation of common decisions can also vary between partners.

In this context, the concept of "supraregional institution" depicts a common institution with legal capacity to implement the decisions of the involved cross-border (sub)-state authorities. In doing so, it institutionalises, represents and perpetuates the cross-border region. This concept results from a comparison with the European integration process, which triggers a "spill-over effect", ${ }^{49}$ characterised by different phases. The most integrated of these is the construction of a sui generis legal order, independent from the member states' own legal order. ${ }^{50}$ As a result of this integration process, a supranational political system emerges, having deep implications not only at supranational but also at nation-state and substate levels. We understand the emergence of a cross-border level of governance (through institution-building processes) as being closely intertwined with the European integration process. ${ }^{51}$ Conceptualisations analysing supranational institutions can accordingly be applied to the emergence of the transnational level of governance. Supranational institutions have been widely analysed both in political science and $\operatorname{law}^{52}$; two concepts are particularly illuminating for the cross-border context. First, the emergence of a supranational political system results from a continuum. ${ }^{53}$ In the cross-border context, we place emphasis on the process 
through which institutions progressively structure and perpetuate the cross-border region. Second, the concept of decisional supranationalism emphasises the "institutional framework and the decision-making process by which Community policies and measures are, in the first place, initiated, debated and formulated, then promulgated and finally executed" ${ }^{54}$ Three criteria are identified: 1) the independence of the institution (e.g., independent staff, budget), the decision-making process (e.g., quality majority voting) and the execution of measures directly undertaken by the institution or under its supervision. ${ }^{55}$

Applying these conceptualisations to our analysis, interregional crossborder cooperation is characterised by the pre-eminence of and the balance between each (sub)-state authority, from the negotiation of common rules of the game at the political level, through the decision-making process, to the implementation of decisions by administrations. Interregional cooperation is a policy field directly driven by and dependent on (sub)-state authorities. While keeping the balance between (sub)-state authorities, cross-border supraregionalisation is a process through which, besides them, a cross-border institution embodies and perpetuates the cross-border region in construction. It represents the interests of the cross-border region as a whole. In contrast to interregional cooperation, supraregional cooperation relies on rules of the games institutionalised through a legal agreement conferring certainty and continuity on it. Applying the criteria identified by Weiler in this context, cross-border supraregional institution(s) conduct the activities that have been conferred on it with 1) independence (e.g., legal capacity, own staff) while 2) the decision-making process includes majority voting. The supraregional institution 3) implements the tasks that cannot be handled solely by the authorities involved. Since they hold the political legitimacy, (sub)-state authorities remain the only decisional body in a supraregional setting. However, the cross-border institution plays a crucial initiative role; it implements the cross-border project for the whole area, consequently contributing to embodying and perpetuating the cross-border cooperation. These definitions are operationalised in Table 1. Since cross-border supraregionalisation is first and foremost a process, a cross-border institution can therefore, within its structuring process, at the same time cover interregional and supraregional elements. Depending on the stage of cooperation, elements of inter- and supraregional cooperation may coexist.

Because of the legal specificities of the EGTC tool (e.g., legal personality), this instrument de facto locks in the institutionalisation of the cooperation. The decisional capacity of (sub)-state authorities regulates the impact of these legal provisions; they can decide to speed up, limit or restrain the institutionalisation process. The following section investigates how the EGTC institutionalises the cooperation (third column of Table 1). 


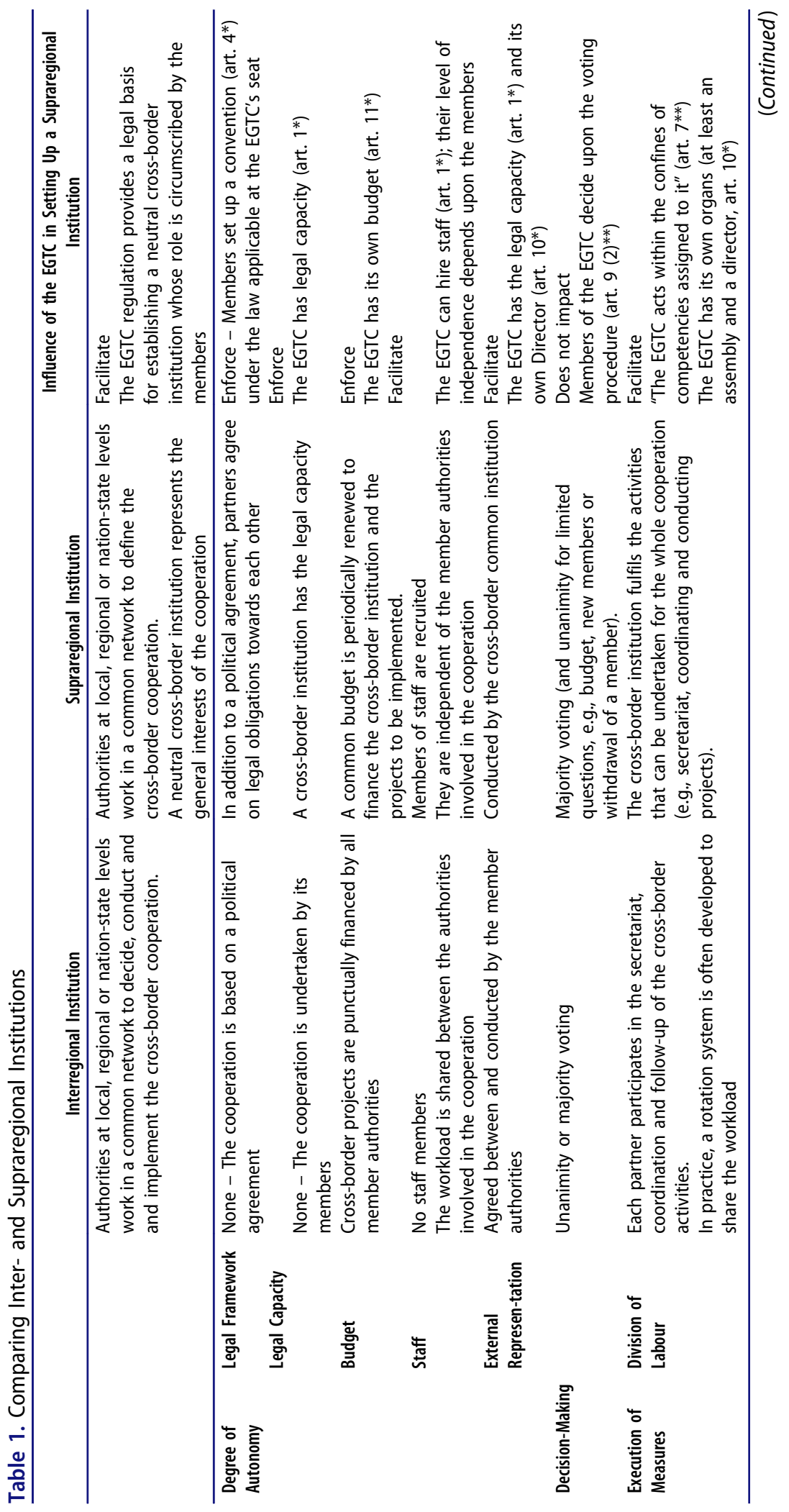




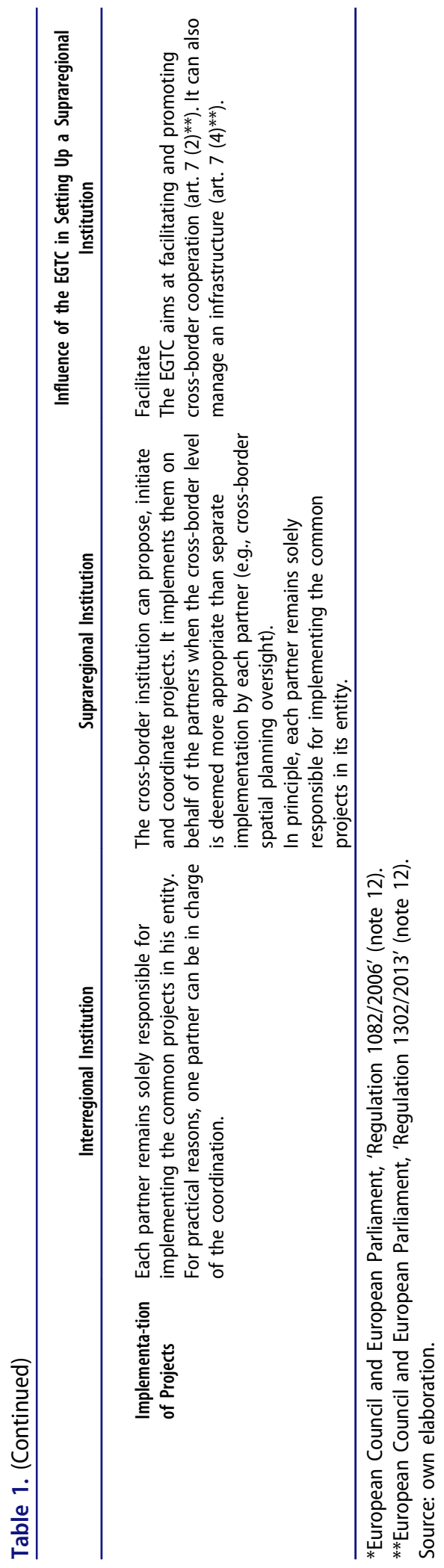




\section{The EGTC, a Tool for Establishing a Supraregional Institution}

At this stage, a preliminary remark is needed. Despite the support of numerous lawyers for creating a European law regulating cross-border cooperation, ${ }^{56}$ the complexity of such an endeavour and the reluctance of some member states ('paradiplomacy' being a key reason ${ }^{57}$ ) encouraged the EU to opt for a more pragmatic way. The EGTC regulation represents a compromise: first, this framework can support the management of EU funds ${ }^{58}$ as the Commission insisted. Second, it answers some of the key claims (e.g., legal personality) made by lobbying organisations (e.g., Association of European Border Regions ${ }^{59}$ ) without actually developing a new section in European law dedicated to territorial cooperation. The EGTC indeed creates a European legal tool, the application of which, however, relies on national law. ${ }^{60}$ The major advantage of this compromise is third to avoid any interference with the member states' own division of competence between the state and the regional level and to leave them full authority to decide on how provisions shall be implemented. For example, centralised countries (e.g., France, Italy) have one implementing provision while federated states make their own provisions in Austria, Belgium and Germany. Fourth, each member state keeps its individual imprint at least at two stages: when transposing the regulation into national law, and when approving an EGTC involving sub-state authorities on its territory. ${ }^{61}$ The latter was one of the main bottlenecks during the negotiations. ${ }^{62}$ Member States have a power to exercise ex-ante control, meaning that "the Member States must allow the participation in an EGTC, unless certain conditions are not fulfilled" while the commission makes sure to "pay close attention" to the way the regulation is implemented. ${ }^{63}$

This situation has two major consequences. Given the political support of the EU for EGTCs, cross-border areas may also use this instrument to increase their visibility on the European map, without however bypassing the nation-states. Then, while this regulation has the advantage of providing a unified framework for territorial cooperation, the transposition into national law might lead to a fragmentation of cross-border cooperation standards. ${ }^{64}$ For example, while the new member state Croatia showed great interest in this regulation and transposed it quickly, national provisions are still missing in some federated states of Austria, Belgium and Germany. ${ }^{65}$ In France, the very specific legal status of the EGTC (syndicat mixte) is deemed unfortunate. ${ }^{66}$ Paradoxically, when establishing an EGTC, (sub)state authorities should launch a comparative law study to select the most favourable law under which the EGTC in preparation should be governed.

Despite these formal challenges, three aspects of the EGTC regulations contribute directly to institutionalising the cross-border cooperation, thus providing the ground for constituting a transnational scale of governance to 
which (sub)-state authorities steer their efforts when establishing a crossborder strategy. First, conferring legal personality ${ }^{67}$ on the EGTC is one of the main novelties; it contributes also directly to its autonomy. It has its own budget, ${ }^{68}$ may employ staff, launch and answer calls for tenders, and participate in projects relating to territorial cooperation. ${ }^{69}$ In return, it is liable for its debts. ${ }^{70}$ Second, the regulation provides a general orientation on how the EGTC shall function (with a convention ${ }^{71}$ ) and organise itself (with statutes $^{72}$ ). Each EGTC shall also have an assembly (gathering of its members) and a director representing it. ${ }^{73}$ When establishing an EGTC, (sub)state authorities de facto institutionalise their cooperation, moulding their own "rules of the game" into the EU and national frameworks. From "kleine Außenpolitik", where rules of the game are essentially political, (sub)-state authorities set up a legally binding agreement between themselves. With staff and tasks, the EGTC embodies the cross-border cooperation, whereas under a strict interregional cooperation it is embodied in a network where each individual member's core activities are primarily relating to a (sub)-state authority. In this latter situation, the cross-border cooperation is in the background of numerous attributions. The institutionalisation process locks in a process where one institution embodies the cooperation and is in charge of specific tasks in order to conduct and concretise it. If such a framework is less flexible, it also implies obligations and rights for each member, thus providing an element of "certainty" to the cooperation and leaving aside the "institutional ambiguity" ${ }^{74}$ Third, a set of tasks is devoted to the EGTC. ${ }^{75}$ The regulation mainly defines two criteria to delimit the effective tasks that an EGTC may undertake. On the one hand, an EGTC aims at "facilitat[ing] and promot[ing] territorial cooperation to strengthen Union economic, social and territorial cohesion, and the overcoming of internal market barriers". ${ }^{76}$ This broad definition opens a wide spectrum of possible tasks to be undertaken by an EGTC. At the same time, this provision implies positioning the EGTC vis-à-vis the EU regional policy, even when it is financially independent. This situation reinforces the "branding" trend, ${ }^{77}$ where (sub)-state authorities are encouraged to identify their endogenous potential, ${ }^{78}$ develop their own strategy. ${ }^{79}$ Establishing an EGTC is one way to "get on the map". On the other hand, a crucial question relates to the extent of the tasks that an EGTC can be given by its members. If it is clear that an EGTC "shall act within the confines of the tasks given to it ... and falling within the competence of every member", can (sub)-state authorities be members without having the same set of competence as the other members? The member state whose member is not competent for all the tasks specified in the convention shall approve its participation ${ }^{80}$ and has therefore a role of arbitration in respect of applying its own constitutional law. ${ }^{81}$ This rather technical consideration is crucial: under the control of the member states, it allows (sub)-state authorities to have asymmetric sets of competences to 
create an EGTC. If it were otherwise, the added value of this regulation would have been largely undermined. It provides the opportunity for substate authorities having limited sets of competences to be part of such cooperation without limiting its extent (e.g., Francophone and Germanspeaking communities in Belgium, mostly competent for language and education). This provision confirms the gatekeeper role of the member states that can draw the limits of such cross-border cooperation. The practical interpretation of this provision will be crucial for the effective extent of the cooperation. All in all, this tends to demonstrate that when associating (sub)state authorities with wide-ranging sets of competence, the EGTC can be institutionalised, for example, to implement a common cross-border strategy or to run infrastructure projects (e.g., the Cerdagne cross-border hospital at the French and Spanish borders which involves authorities from municipal, local and national levels). ${ }^{82}$

Following our definition of supraregional institution, the EGTC regulation on the one hand ensures the autonomy of the cross-border institution. It also sets the ground for empowering the EGTC with specific tasks to be undertaken for the cooperation as a whole and for ensuring its external representation. The EGTC can thus play a key role in executing measures on behalf of the cooperation. Nevertheless, this regulation is rather neutral when it comes to the decision-making process that can remain unanimous, while a supraregional institution would imply some majority voting. This regulation therefore triggers the institutionalisation of the cross-border cooperation without automatically leading to a supraregional institution. It remains to be seen how (sub)-state authorities will use this institutional room for manoeuvre and whether they will confer capacity-building to a common cross-border institution. In the next section, we analyse how this framework is implemented in the Greater Region.

\section{The Greater Region SaarLorLux: Halfway Between "Kleine Außenpolitik" and Supraregionalisation?}

During the last 150 years, the cross-border region currently known as the Greater Region was often the focus of unwanted international attention, and of the last European wars. ${ }^{83}$ In the 1950s, while the European community for steel and coal came into being, SaarLorLux played an important role on the map. Its homogenous economic profile of the "coal and steel triangle" ${ }^{84}$ was its living reality until the crisis in these sectors in the 1960s and 1970s. ${ }^{85}$ The past difficult economic reconversion explains the nowadays contrasted picture (structural change to the dynamic finance sector in Luxembourg, and to some extent to the automotive sector in Lorraine and Saarland). ${ }^{86}$ The Greater Region is currently well known by border scholars: on the one hand for being the largest European cross-border area of cooperation, ${ }^{87}$ 
and most notably, on the other hand, for having the most significant concentration of cross-border commuters $\left(213,400\right.$ persons in 2013). ${ }^{88}$ The resulting diverse functional interdependencies encouraged the (sub)-state authorities to set up a common strategy in 2008, labelled "Metroborder" (cross-border polycentric metropolitan region). ${ }^{89}$ The "Summit of the Executives" $" 90$ is the driving force behind this strategy; it is also the main political institution of the region. ${ }^{91}$ Created in 1995, it gathers the highest political representatives of each associated (sub)-state authority and works on the basis of a two-year rotating presidency. This setting is unique in Europe, since it brings together a nation-state (Luxembourg), three federated states (Rhineland-Palatinate, Saarland and Wallonia), two federated political communities (German-speaking and Francophone communities in Belgium) and four decentralised authorities (Prefecture of Lorraine, Lorraine Region, Meurthe et Moselle and Moselle local authorities, Figure 1).

The effectiveness of the cooperation relies upon a three-step procedure involving systematically each individual partner, and therefore being strictly interregional:

- Together, the political representatives of the (sub)-state authorities involved meet and take decisions on the content and extent of the cooperation. This gathering legitimises the common decision and the cross-border cooperation as a whole (kleine Außenpolitik);

- Thematic working groups gathering together administrative representatives of each (sub)-state authority concretise the political decision;

- Each (sub)-state authority implements the decision (operational implementation).

This setting, involving many (sub)-state authorities, having their own political agendas and election rhythms, makes the cooperation challenging. Representatives from (sub)-state authorities openly acknowledge a lack of continuity between the successive presidencies. ${ }^{92}$ In this cooperation scheme, where rules of the game rely upon each (sub)-state authority's own staff, cross-border projects are punctually financed either by all members or by INTERREG projects. As in other cross-border regions, some (sub)-state authorities regard the INTERREG programme as one way of operationalising "their" own cross-border projects, while others place emphasis on the European source and purpose of this funding scheme. This ambivalence is inherent in the INTERREG programme. ${ }^{93}$ Recently, (sub)-state authorities have set up two EGTCs, whose features are compared in Table 2. The first EGTC undertakes the role of managing authority of the INTERREG IVA Greater Region programme. ${ }^{94}$ The second EGTC institutionalises the cooperation undertaken within the framework of the Summit, conferring on it a budget, staff and slightly changing the "rules of the game". 


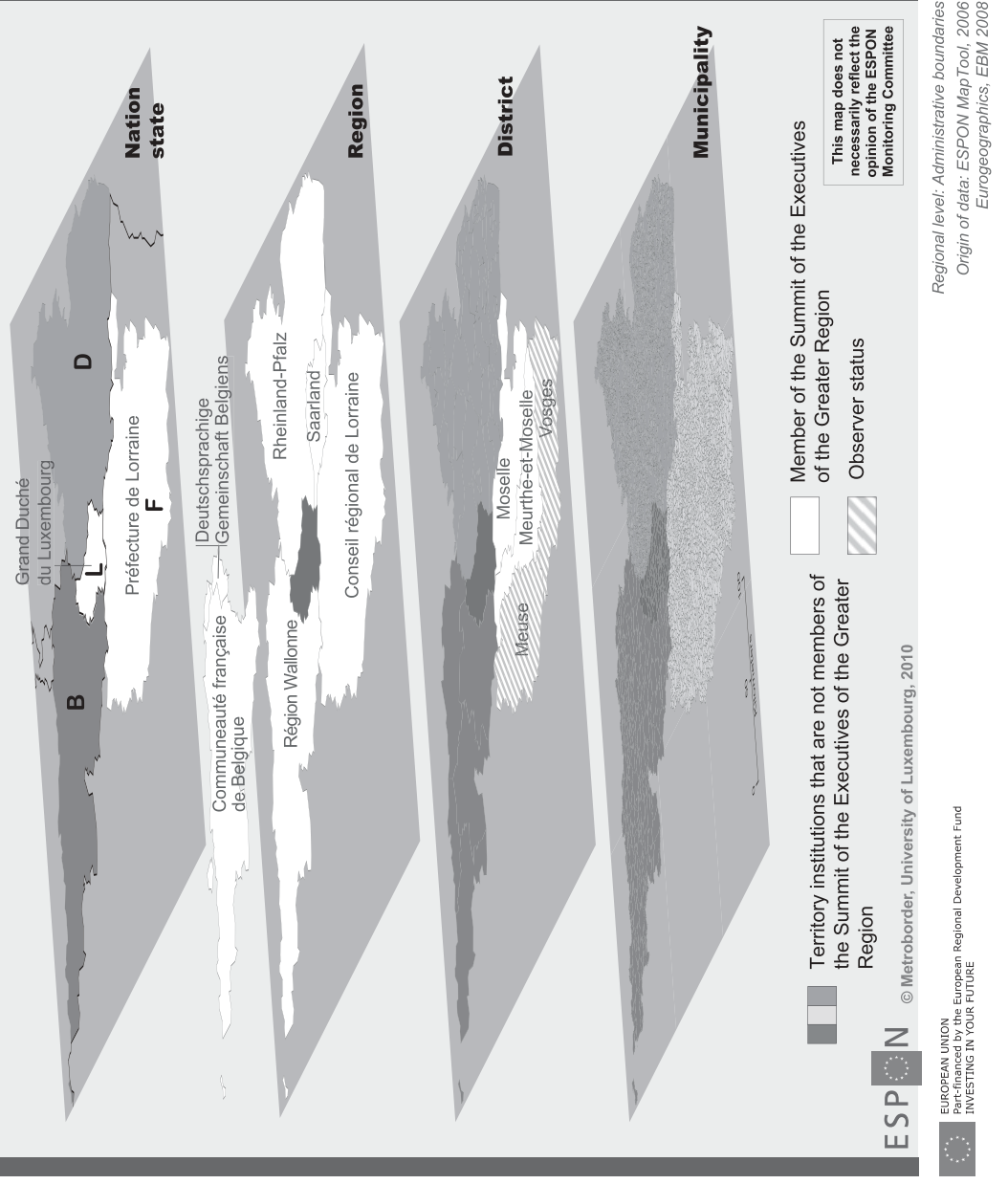

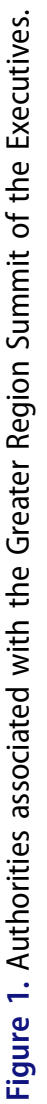


Table 2. Main Characteristics of the EGTCs in the Greater Region

\begin{tabular}{|c|c|c|}
\hline & GECT - INTERREG Programme Greater Region ${ }^{1}$ & $\begin{array}{l}\text { GECT Secretariat of the Summit of the Greater } \\
\text { Region }\end{array}$ \\
\hline \multicolumn{3}{|c|}{ Main Characteristics } \\
\hline SEAT & Metz (FR), Prefecture of the Lorraine region & Esch s/ Alzette (LU) \\
\hline APPLICABLE LAW & French & Luxembourgish \\
\hline MEMBERS & $\begin{array}{l}\text { All members depicted in Figure } 1 \\
\text { (including Meuse département as a full } \\
\text { member, Vosges département is not } \\
\text { member) }\end{array}$ & $\begin{array}{l}\text { All members depicted in Figure } 1 \\
\text { (except Meuse and Vosges départements) }\end{array}$ \\
\hline LANGUAGES & \multicolumn{2}{|c|}{ German and French } \\
\hline
\end{tabular}

\section{Degree of Autonomy}

\begin{tabular}{|c|c|c|}
\hline DATE OF CREATION & 1 April 2010 & 28 Aug. 2013 \\
\hline AND DURATION & $\begin{array}{l}\text { Until the closure of the INTERREG IV A } \\
\text { programme, extended until the end of } 2015\end{array}$ & Indefinite duration \\
\hline ROLE & $\begin{array}{l}\text { Managing authority of the INTERREG IV A } \\
\text { programme (2007-2014), as defined by the } \\
\text { EU structural funds regulations }\end{array}$ & $\begin{array}{l}\text { Administrative secretary of the Summit, } \\
\text { coordination of its presidencies and } \\
\text { organisation of its working groups }\end{array}$ \\
\hline BUDGET & EU structural funds & Budget shared between the members \\
\hline STAFF & $\begin{array}{l}\text { Bilingual staff (independent of the members) } \\
\text { the activities }\end{array}$ & recruited to support the implementation of \\
\hline $\begin{array}{l}\text { EXTERNAL } \\
\text { REPRESENTATION }\end{array}$ & $\begin{array}{l}\text { Ensured by the members and the president } \\
\text { (Prefect of the Lorraine Region, acting in the } \\
\text { name of the EGTC and representing it) }\end{array}$ & $\begin{array}{l}\text { Not yet clear from the convention and } \\
\text { statutes. Either the rotating presidency } \\
\text { (changing every two years) or the staff }\end{array}$ \\
\hline \multicolumn{3}{|l|}{ Decision Making } \\
\hline $\begin{array}{l}\text { DECISION-MAKING } \\
\text { BODY }\end{array}$ & General assembly gathering all members & \\
\hline $\begin{array}{l}\text { DECISION-MAKING } \\
\text { PROCESS }\end{array}$ & $\begin{array}{l}\text { Decisions are taken by a unanimous vote for } \\
\text { all questions }\end{array}$ & $\begin{array}{l}\text { Each territorial component (Lorraine, } \\
\text { Luxembourg, Rhineland-Palatinate, } \\
\text { Saarland, Wallonia) has four votes. } \\
\text { Decisions are taken by a majority of three } \\
\text { territorial components (gathering eleven } \\
\text { votes or more, art. 13.1, statutes) }\end{array}$ \\
\hline
\end{tabular}

\section{Execution of Measures}

DIVISION OF Management board gathering LABOUR representatives from all members and the director in charge of the "administrative daily management of the managing authority" of the programme (art. 17)

The EGTC ensures the secretariat of the Summit and the coordination of the Summit's Presidency (art. 2, statutes) Each member is responsible for implementing the decisions in its entity

IMPLEMENTATION The EGTC is only in charge of the managing OF PROJECTS authority of the INTERREG IV A Greater Region programme

The manager (member of staff) assists the president (rotating presidency) and ensures the daily management of administrative and logistic activities (art. 14 , statutes)

\footnotetext{
${ }^{1}$ Information in this column is based upon 'Règlement grand-ducal du 11 décembre 2009 autorisant l'Etat du Grand-Duché de Luxembourg à adherer au groupement européen de cooperation territoriale (GECT) "Interreg-Programme Grande Région" et approvant le projet de convention relative audit groupement et le projet de statuts de celui-ci', Memorial Journal Official du Grand-Duché de Luxembourg A 243 (Dec. 2009) pp. $4345-4360$.

${ }^{2}$ Information in this column is based upon 'Arrêté grand-ducal du 30 juillet 2013 autorisant la creation du Groupement européen de Coopération territoriale (GECT) "Secrétariat du Sommet de la Grande Région"', Memorial Journal Official du Grand-Duché de Luxembourg A 155 (Aug. 2013) pp. 2999-3016.

${ }^{3}$ Nonetheless, for the following questions, decisions are taken by a unanimous vote: accession of new members (article 9.2), the loss of membership quality (article 10), exclusion of a member (art. 11), budget (art. 18), change of statutes (article 19) and dissolution of the GECT (art. 20).

Source: own elaboration.
} 
When comparing the EGTCs' features to the definition of supraregional institution presented earlier (Table 1), one notices their very limited degree of autonomy. Despite the fact that both EGTCs have legal capacity, their own budget and staff, their role remains limited - at least from the way it is formulated. A managing authority plays a central role for the effective administration of an INTERREG programme, but it is mainly executive, excluding any initiative. Apart from the European visibility that it confers on the Greater Region (the only EGTC of this kind in Europe), one can ask about the effective added value of the EGTC tool, since the managing authority's role is clearly defined in the EU regulation and the managing authority is, by definition, an authority with legal personality. The EGTC Secretariat of the Summit's role is also formulated in a rather restricted manner; it is its "administrative secretariat" and the daily business is taken care of by a "manager". In respect of the institutional context presented earlier, this EGTC aims first and foremost at establishing a permanent body acting as a conveyor belt between the decision-making process and the working groups' implementation.

As to the decision-making process, members of each EGTC take the decisions gathered in an assembly in both cases. Decisions are taken unanimously in the case of the EGTC INTERREG while majority voting is the rule at the EGTC Summit. This latter element represents the most visible "power twist" to be observed in this particular case. It institutionalises five "territorial components" (each corresponding to one of the territorial entities of the Greater Region). The decision-making process is also simplified, with the majority voting procedure for matters relating to the daily management of the EGTC, thus avoiding blocking positions. This rather technical provision also addresses directly the "multi-level mismatch" and the important number of members. This voting procedure de facto encourages members of the same territorial component to act in concert prior to the cross-border assemblies, in order to be stronger in the negotiation at cross-border level. This reinforces territorial components having only one member (Luxembourg, Saarland and Rhineland-Palatinate). This voting procedure shifts the multilevel mismatch from the cross-border interregional cooperation level back towards each territorial component itself. This could encourage each territorial component to design its own common strategy and vision for the cross-border cooperation as a whole. Under the pretext of respecting the institutional setting of each (sub)-state region, both majority voting and working with territorial components were hardly discussed a couple of years ago. ${ }^{95}$

As to the implementation of projects, both EGTCs conduct tasks on behalf of their members, thus allowing a transnational scale of governance to emerge, both at the level of decision (assembly of the EGTCs) and at the level of the operational implementation (EGTCs'staff). In the case of the 
EGTC INTERREG IVA, this is nonetheless not new, since it undertakes the usual management structure of an INTERREG operational programme. It nevertheless changes slightly the picture presented earlier as to the EGTC Summit which institutionalises further its functioning at the decisional level (voting procedure) and at the operational level (common staff implementing the Summit's presidency priorities and following up the working groups). In both cases, the EGTC is used as an operational tool to facilitate the cooperation between its members; it is not yet used to increase the visibility of the cooperation to the citizens. The presidency is held by one of its members, hence conferring a rather strong political backing on these institutions, whose tasks are mostly administrative and operational. It reveals the members' willingness to keep their imprint on the daily cooperation and to carry out the functions of external representation.

In addition, interviews ${ }^{96}$ conducted in 2011, while (sub)-state authorities were negotiating the establishment of the EGTC Summit, demonstrate that the EGTC is first and foremost interpreted through the very particular light of each (sub)-state authority. It is rare that experts emphasise the added value for the "cross-border region" as a whole. Depending on their specific institutional situation, experts interviewed seem to have different understandings of the EGTC and its impact on cross-border governance:

- Experts working in federated states perceive the EGTC rather as a legal tool, amongst others, whose added value is mainly to be able to associate a state, such as Luxembourg.

- Experts working at the national level in Luxembourg emphasise the link that the EGTC creates with the EU; it opens up new opportunities (e.g., visibility, agenda-setting at the EU level). There is also a concern that the cooperation would progressively have to "label" itself towards EU goals. In these particular cases, the EGTC appears mainly as a way of formalising the cooperation and of appearing on the European map.

- In decentralised authorities, conversely, the EGTC seems to change their perceived relationship with the EU but also towards the other (sub)-state authorities involved. It is seen as a possible strategy for expressing typical cross-border concerns at the nation-state and EU levels.

The interregional prism prevails: the EGTC appears as a tool for attempting to twist the very specific power relation each (sub)-state authority has in the cross-border, national and European context.

As a corollary, experts understand the EGTC as a way of increasing the national and European visibility of the cross-border cooperation. Since it is promoted by the EU and transposed into national law, the EGTC is perceived as a tool that mechanically reinforces the multi-level interdependencies. On 
the contrary, few experts understood the EGTC as a supraregional tool: "We don't need an EGTC to write minutes of the meetings, to manage the communication and to liaise between the working groups. This is nonetheless another story if is meant to support and implement the strategic vision of the Greater Region" (expert interview). This minority opinion demonstrates that despite being currently unused, the supraregional potential of the EGTC tool appears as a clear policy option for some experts.

Notwithstanding its long-running cross-border cooperation (1970s) and the recent establishment of two EGTCs, the cooperation in the Greater Region remains mostly interregional. In a couple of years, however, the decision-making process has evolved considerably. It confirmed the institutional weight of the EGTC's members, whilst avoiding blockage situations and pushing for more strategy-oriented decision-making. While experts perceive the EGTC's supraregional potential, this instrument is currently mainly used for related aims: formalisation, institutionalisation, visibility and individual positioning at the cross-border and wider national and European levels. In both cases, the EGTCs institutionalise the cross-border cooperation, crystallising into law and enforceable convention and statutes the previously negotiated but diffuse rules of the game. The future interpretation of the statutes and conventions by the EGTCs' members and staff shall reveal whether this mainly interregional cooperation progressively shifts towards supraregional cooperation. As a region under construction (Paasi, 1986), cross-border cooperation is a long-running process.

\section{Conclusion}

We opened this contribution with Perkmann's analysis that cross-border regions "do not appear particularly successful in constituting new, transnational scales of governance". ${ }^{97}$ Even if the EGTC does not seem to have a direct impact on solving the challenge of developing a political legitimacy of its own, it facilitates the emergence of an autonomous cross-border entity in a capacity to execute measures (e.g., implementing a strategy, running infrastructure) on behalf of its members. This tool consequently launches an institutionalisation process through which an embryonic transnational scale of governance is structured. (Sub)-state authorities can then use this platform to develop a supraregional institution, hence supporting the construction and the perpetuation of the region. The degree of "supraregionalness" depends for example on the nature of the measures it executes, on the decisionmaking process (e.g., majority voting) and its external visibility. Within recent years, the widespread use (both geographically and content-wise) of the EGTC has made it an unavoidable tool for practitioners interested in territorial governance. 
Yet, when analysing how the Greater Region - equipped with 40 years of cross-border cooperation - has implemented it, one can conclude that the supraregional potential of this tool was, until now, mobilised in a limited manner. The contribution demonstrates that - a couple of years after the EU regulation entered into force - (sub)-state authorities grasp this tool for many reasons not directly linked to the supraregional potential we identified. Institutionalising their existing cross-border cooperation, going beyond the "kleine Außenpolitik" and appearing on the EU map are key aspects. For these laboratories of Europe, the national and EU scales continue to be inevitable for solving concrete questions (e.g., transnational transport connections) and acknowledging cross-border specificities, as the Lisbon Treaty did in 2007. These "pragmatic" reasons seem to leave in the background - at least for the moment and in the Greater Region - the use of the EGTC as a supraregional tool, supporting the implementation of a cross-border strategy visible to the citizens. Conceptualising the cross-border cooperation as a region under construction helps to illuminate this paradox by emphasising the long-term process through which this region emerges and is perpetuated. The EGTCs are first interpreted in the light of each (sub)-state authority's positioning within the multi-level governance setting. Its legal features (e.g., legal personality) and its application mediated through the member states contribute to reshuffling power bargaining across the levels of governance. In this sense, the EGTC contributes to institutionalising a cross-border scale of governance, used as a platform for negotiation and power bargaining both within the region in construction and towards national and European levels. The upcoming years will reveal how the EGTC Summit in particular ${ }^{98}$ will position itself within the region in construction. Its "supraregionalness" will depend on its capacity to operationalise - through its individual project - the interests of the Greater Region as a whole. This is without any doubt a longterm task, depending on the one hand on the vision and on the willingness of the EGTC's staff to engage in such an interpretation of the cross-border challenges, and on the other hand on the readiness of the Greater Region's members to engage with the emergence of a supraregional institution embodying the interests of the region as a whole and not only representing the addition of the members' interests (interregional cooperation). The convention and statutes of the EGTC Summit as well as the interviews conducted show that the (sub)-state institutions involved have left the door open for the concretisation of such a vision in the future. ${ }^{99}$ Yet, as demonstrated earlier, this vision is currently a minority one. Its further concretisation might depend on the evaluation of the EGTC Summit's activities to be conducted in a few years' time. ${ }^{100}$

This contribution has concentrated on the potential opened by the EGTC and on the political interpretation of this new institutional room for manoeuvre. Some academic studies have investigated how various individual 
daily border crossing practices in the Greater Region (for work, ${ }^{101}$ housing, shopping and culture ${ }^{102}$ ) contribute to shaping a specific appropriation of the cross-border space and a sense of identity, ${ }^{103}$ despite the limited visibility of its political construction. As conceptualised by Paasi, ${ }^{104}$ the construction of a region is a complex, multifaceted process involving a wide range of actors. Both cross-border practices and the manifold cross-border functional interdependencies demonstrate the need for further institutional cross-border cooperation. The EGTC represents a significant institutional step to reinforce its concrete identification by the citizen. In June 2015, the inauguration of the "house of the Greater Region", hosting all cross-border institutions in the same place (Esch-sur-Alzette, LU), widely advertised in the local press, demonstrated the attempt to increase their visibility. Again, the next few years will reveal the effectiveness of such political wills in reconciling the political construction with the citizens' needs.

\section{Acknowledgements}

This paper expands on some themes addressed in the $\mathrm{PhD}$ thesis "Supra-régionalisation transfrontalière? Grande Région SaarLorLux", which was conducted under the supervision of Prof. Dr. Christian Schulz and Prof. Dr. Tobias Chilla and was defended in March 2013. The author wishes to thank them for their support and encouragements. The author is also grateful to three anonymous referees for their valuable comments.

\section{Notes}

1. O.-T. Kramsch, 'Reimagining the Scalar Topologies of Cross-Border Governance: Eu(ro)regions in the Post-Colonial Present', Space \& Polity 6/2 (2002) pp. 169-196.

2. ESPON and IGEAT, Study on Urban Functions - Final Report (Luxembourg: March 2007), available at <http://www.espon.eu/export/sites/default/Documents/Projects/ ESPON2006Projects/StudiesScientificSupportProjects/UrbanFunctions/fr-1.4.3_ April2007-final.pdf>.

3. L. Hooghe and G. Marks, 'Types of Multi-Level Governance', European Integration Online Papers 5/11 (2001).

4. J. Häkli, 'Re-Bordering Spaces', in K.-C. Kox, M. Low, and J. Robinson (eds.), The SAGE Handbook of Political Geography (London: SAGE Publications 2008) p. 477.

5. M. Perkmann, 'Euroregions: Institutional Entrepreneurship in the European Union', in M. Perkmann and S. Ngai-Ling (eds.), Globalization, Regionalization and CrossBorder Regions (Palgrave Macmillan 2002) p. 109.

6. Ibid.

7. Ibid. and O. Kramsch and B. Hooper (eds.), Cross-Border Governance in the European Union (London: Routledge 2004).

8. J. Beck, Netzwerke in der transnationalen Regionalpolitik: Rahmenbedingungen, Funktionsweise, Folgen (Baden-Baden: Nomos).

9. A. Church and P. Reid, 'Cross-border Co-operation, Institutionalization and Political Space across the English Channel', Regional Studies 33/7 (1999) pp. 643-655. 
10. M. Perkmann and N.-L. Sum, 'Globalization, Regionalization and Cross-Border Regions: Scales, Discourses and Governance', in M. Perkmann and S. Ngai-Ling (eds.), Globalization, Regionalization and Cross-Border Regions (London: Palgrave Macmillan 2002) pp. 3-24.

11. Häkli, 'Re-Bordering Spaces' (note 4) p. 477.

12. European Council and European Parliament, 'Regulation No. 1082/2006 on a European Grouping of Territorial Cooperation (EGTC)', Official Journal of the European Union L 210 (July 2006) p. 19. After an open consultation process conducted by the EU Commission (see EC, Report from the Commission to the European Parliament and the Council on a European Grouping of territorial cooperation Brussels: $\operatorname{SEC}(2011) 981$ final, $\operatorname{COM}(2011) 462$ final), this regulation was amended by: European Council and European Parliament, 'Regulation No. 1302/ 2013', Official Journal of the European Union L 347 (Dec. 2013) pp. 303-319.

13. MOT, Groupements européens de Coopération Territoriale (GECT), (March 2015) map published online, available at <http://www.espaces-transfrontaliers.org/en/ resources/cartes/maps/show/les-gect-crees-en-europe/>.

14. N. Levrat, Le Groupement européen de Coopération Territoriale (GECT), (Brussels: Committee of the Regions 2007) CDR117-2007_ETU; A. Gautier-Audebert, 'Le GECT, Groupement européen de Coopération Territoriale, un nouvel Outil à Simplifier', RLCT 92 (July/Aug. 2013) pp. 41-50; P. Bußjäger, A. Gamper, E. Happacher, and J. Woelk (eds.), Der europäische Verbund territorialer Zusammenarbeit (EVTZ): Neue Chancen für die Europaregion Tirol-SüdtirolTrentino (Vienna: Braumüller Schriften 113, 2011); M. Pechstein and M. Deja, 'Was ist und wie funktioniert ein EVTZ ?', Europarecht 3 (2011) pp. 357-383.

15. European Council and European Parliament, 'Regulation No. 1082/2006' (note 12) article 1 (3). Instituted in 1985, the European Economic Interest Grouping (EEIG) also has the status of a legal person. It aims at facilitating and developing the economic activities of its members and ultimately to facilitate transnational cooperation between economic entities. As a consequence, this tool is mainly economic, and thus poorly adapted to cross-border cooperation between mostly public entities (see European Council and European Parliament, 'Regulation No. 1082/2006' (note 12) $\$ 4$ and N. Levrat (note 14) p. 41).

16. B. Elissalde and F. Santamaria, Lexique de l'Aménagement du Territoire européen (Paris: Lavoisier 2008) p. 105. For an overview of Euroregions' organisational settings and fields of activities, see EC and AEBR, Practical Guide to Cross-Border Cooperation (Luxembourg: European Commission 2000) p. 9.

17. Pechstein and Deja (note 14) p. 360.

18. European Council and European Parliament, 'Regulation No. 1082/2006' (note 12) article 3; Gautier-Audebert (note 14). Therefore, when referring to a cross-border cooperation involving sub-state and state authorities, we use the expression "(sub)state authorities".

19. This possibility was one decisive point in the negotiations of the regulation; EC Regional Policy, 'The European Grouping of Territorial Cooperation', Inforegio Panorama 24 (Dec. 2007) p. 11.

20. Ibid., art. 17; and Gautier-Audebert (note 14).

21. Committee of the Regions, EGTC Developments on the Ground: Added Value and Solutions to Problems 2010, available at <https://portal.cor.europa.eu/egtc/ Publications/Documents/RAPPORT\%20FINAL\%20SANS\%20TC\%20R\%C3\% A9union\%20Coter\%2025062010\%20EGTC\%2028052010_.pdf>; INTERACT, The European Grouping of Territorial Cooperation (EGTC) - What use for European 
territorial Cooperation Programmes and Projects?, 2008, available at $<\mathrm{https} / /$ portal. cor.europa.eu/egtc/discovertheegtc/Documents/INTERACT_Handbook_on_the_ EGTC_November_2008.pdf>; MOT, Guide de la Coopération Transfrontalière Groupement Européen de Coopération Territoriale (Paris: MOT 2011); MOT, Cadre Juridique de la Coopération Transfrontalière - Outils Juridiques au Service des Projets Transfrontaliers (Paris: MOT 2013); BMVI, Leitfaden zur Gründung eines EVTZ für Akteure der grenzüberschreitenden Zusammenarbeit (Bonn: BMVI 2014).

22. V. Biot, 'Les Systèmes de Gouvernance des Territoires Transfrontaliers: La Mise en Euvre du Règlement Européen sur les GECT (Groupements Européens de Coopération Territoriale)', Belgeo 1 (2013).

23. E. Nadalutti, 'Does the 'European Grouping of Territorial Co-operation' Promote Multi-Level Governance within the European Union?', JCMS 51/4 (2013) pp. 756-771.

24. Perkmann (note 5) p. 9.

25. European Council and European Parliament, 'Regulation No. 1082/2006' (note 12).

26. Ibid., article 7.

27. A. Paasi, 'The Institutionalization of Regions: A Theoretical Framework for Understating the Emergence of Regions and the Constitution of Regional Identity', Fennia 164 (1986) p. 110.

28. Ibid., p. 121.

29. AGEG - Arbeitsgemeinschaft Europäischer Grenzregionen, Zusammenarbeit Europäischer Grenzregionen - Bilanz und Perspektiven (Baden-Baden: Nomos); ESPON and University of Luxembourg, Cross-Border Polycentric Metropolitan Regions - Final Report (Luxembourg: ESPON 2010), available at <http://www. espon.eu/export/sites/default/Documents/Projects/TargetedAnalyses/ METROBORDER/METROBORDER_-_Final_Report_-_29_DEC_2010.pdf >.

30. G. Popescu, 'Transcending the National Space: The Institutionalization of Crossborder Territory in the Lower Danube Euroregion', in D. Wastl-Walter (ed.), The Ashgate Research Companion to Border Studies (Farnham: Ashgate 2011) pp. 607-624; C. Johnson, 'Cross-Border Regions and Territorial Restructuring in Central Europe: a Room for More Transboundary Space', European urban and regional studies 16/2 (2011) pp. 177-191.

31. AGEG (note 29); MOT, 'Cadre Juridique' (note 21).

32. H. van Houtum, 'The Mask of the Border', in D. Wastl-Walter (ed.), The Ashgate Research Companion to Border Studies (Farnham: Ashgate 2011) pp. 11-33; K. Zimmerbauer, 'From Image to Identity: Building Regions by Place Promotion', European Planning Studies 19/2 (2011) pp. 243-260.

33. J.-M. Woehrling, 'Les Aspects Juridiques de la Coopération Transfrontalière entre Collectivités et Autorités Locales - Vrais et Faux Problèmes', Revue d'Allemagne et des pays de langue allemande 33/2-3 (2001); H. Comte and N. Levrat (eds.), Aux Coutures de l'Europe - Défis et Enjeux Juridiques de la Coopération Transfrontalière (Paris: L'Harmattan 2006).

34. C. Ricq, 'La Région, Espace Institutionnel et Espace d'Identité' Espaces et Sociétés 42 (1983) pp. 65-78; J. Blatter, 'Debording the World of States: Towards a Multi-Level System in Europe and a Multi-Polity System in North America; Insights from Border Regions', European Journal of International Relations 7 (2001) pp. 175-209; G. MacLeod and M. Jones, 'Renewing the Geography of Regions', Environment and Planning D 19 (2001) pp. 669-695; E. Gualini, 'Cross-Border Governance: Inventing Regions in a Trans-National Multi-Level Polity', disP 152 (2003) pp. 43-53; E. Brunet-Jailly, 'Theorizing Borders: An Interdisciplinary 
Perspective', Geopolitics 10 (2005) pp. 633-649; D. Newman, 'Contemporary Research Agendas in Border Studies: An Overview', in D. Wastl-Walter (ed.), The Ashgate Research Companion to Border Studies (Farnham: Ashgate 2011) pp. 33-48.

35. European Council and European Parliament, 'Regulation No. 1082/2006' (note 12).

36. J. Häkli, 'In the Territory of Knowledge: State-Centered Discourses and the Construction of Society', Progress in Human Geography 25 (2001) pp. 403-422.

37. J. Häkli, 'Cross-Border Regionalisation in the 'New Europe': Theoretical Reflection with Two Illustrative Examples', Geopolitics 3 (1998) pp. 83-103.

38. P. Allmendinger and G. Haughton: 'Soft Spaces, Fuzzy Boundaries, and Metagovernance: The New Spatial Planning in the Thames Gateway', Environment and Planning A 41 (2009) p. 618.

39. Perkmann and Sum (note 10) p. 3.

40. B. Jouve, 'Collectivités Locales et Relations Internationales: Une Emancipation Délicate', Swiss Political Review 1/2 (1995) pp. 138-162.

41. Woehrling (note 33).

42. Comte and Levrat (note 33).

43. T. Chilla, E. Evrard, and C, Schulz, 'On the Territoriality of Cross-Border Cooperation: "Institutional Mapping" in a Multi-Level Context', European Planning Studies 20/6 (2012) pp. 961-980.

44. Ibid.; see also ESPON and University of Luxembourg (note 29) and M. Nagelschmidt, 'Les Systèmes à Niveaux Multiples dans les Régions Transfrontalières en Europe. Le cas du Rhin supérieur et des nouvelles Coopérations à la Frontière est de la RFA', Revue internationale de politique comparée 12/2 (2005) pp. 223-236.

45. M. A. Hajer, 'The Living Institutions of the EU: Analysing Governance as Performance', Perspectives European Politics and Society 7/1 (May 2006) pp. 41-55.

46. Ibid., p. 43.

47. J. Beck, 'Expertise: Kooperations- und Governancestrukturen in grenzüberschreitenden Verflechtungsräumen - Analyse der bestehenden grenzüberschreitenden Strukturen der Zusammenarbeit auf unterschiedlichen Ebenen und räumlichen Zuschnitten', basis for chapter 4 in BVBS (ed.), Metropolitane Grenzregionen. Abschlussbericht des Modellvorhabens der Raumordnung (MORO) „Überregionale Partnerschaften in grenzüberschreitenden Verflechtungsräumen" (Berlin: BVBS 2011) pp. 48-75.

48. J. G. March and J. P. Olsen, Rediscovering Institutions - The Organizational Basis of Politics (New York: The Free Press, A division of Macmillan 1989).

49. E. B. Haas, 'International Integration: The European and the Universal Process', International Organization 15/3 (1961) pp. 366-393.

50. J. Weiler, 'The Community System: The Dual Character of Supranationalism', Yearbook of European Law 1 (1981) p. 268.

51. Häkli, 'Cross-Border Regionalisation' (note 37); and Blatter (note 34) p. 201.

52. Haas (note 49); Weiler (note 50); see also A. Sweet Stone and W. Sandholtz, 'European Integration and Supranational Governance', Faculty Scholarship Series. Paper 87 (1997) available at <http://digitalcommons.law.yale.edu/fss_papers/87>; and S. Saurugger, Théories et Concepts de l'Intégration Européenne (Paris: Presses de Sciences-Po 2009) p. 483.

53. Ibid.; Sweet Stone and Sandholtz (note 52) p. 303.

54. Weiler defines the decisional supranationalism as one facet of supranationalism, complementary to normative supranationalism. The later categorises the legal 
consequences of the European legal order (e.g., norms are directly applicable in the member states and are binding); Weiler (note 50) p. 271. Cross-border cooperation is in itself an expression of EU and national legal orders. Therefore, applying the normative side of supranationalism does not seem relevant for the analysis of the cross-border context.

55. Ibid., p. 272.

56. H. Labayle (ed.), Vers un Droit Commun de la Coopération Transfrontalière? (Bruxelles: Bruylant 2007); see also Comte and Levrat (note 33) and Y. Lejeune, 'Vers un Droit Européen de la Coopération Transfrontalière', Annales de Droit de Louvain, Idées et Perspectives 64/3 (2004).

57. Levrat (note 14).

58. European Council and European Parliament, 'Regulation No. 1082/2006' (note 12).

59. Levrat (note 14).

60. European Council and European Parliament, 'Regulation No. 1082/2006' (note 12) article 16.

61. Ibid., article 4 (3) and European Council and European Parliament, 'Regulation No. 1302/2013' (note 12) see article 1 (5).

62. EC Regional policy (note 19).

63. Ibid. The recent revision of the EGTC (note 12) frames more precisely than regulation 1082/2006 under which conditions the member state may not approve the creation of an EGTC and provides a time frame to reach its decision: European Council and European Parliament, 'Regulation No. 1302/2013’ (note 12) p. $309 \$ 5$.

64. Levrat (note 14).

65. METIS, EGTC Monitoring Report 2013 - Towards the New Cohesion Policy (Brussels: Committee of the Regions 2013), available at <http://cor.europa.eu/en/ documentation/studies/Documents/EGTC-monitoring-report-2013.pdf $>$.

66. Gautier-Audebert (note 14).

67. The EGTC receives "the most extensive legal capacity accorded to legal persons under that Members state's national law"; European Council and European Parliament, 'Regulation No. 1082/2006' (note 12) article 1.

68. Ibid., Article 11.

69. Ibid., Article 7.

70. Ibid., Article 12.

71. Ibid., Article 8.

72. Ibid., Article 9.

73. Ibid., Article 10.

74. Hajer (note 45).

75. European Council and European Parliament, 'Regulation No. 1082/2006' (note 12) article 7.

76. Ibid. An EGTC can be constituted outside the framework of cohesion policy, but its final aim should be territorial cooperation, as defined in Regulation No. 1080/2006: "The development of cross-border economic, social and environmental activities through joint strategies for sustainable territorial development ...; the establishment and development of transnational cooperation ... through the financing of networks and of actions conducive to integrated territorial development, concentrating primarily on the following priority areas: innovation ..., accessibility ...; sustainable urban development ...; reinforcement of the effectiveness of regional policy by promoting: interregional cooperation ...; exchanges of experience ...; actions involving studies, data collection, and the observation and analysis of development trends in the Community" (article 6). As a consequence, an EGTC logically cannot be 
assigned tasks that "concern the exercise of powers conferred by public law ... to safeguard the general interests of the State [...police, regulatory powers, justice and foreign policy]"; European Council and European Parliament, 'Regulation No. 1082/ 2006' (note 12) article 7 (4).

77. Van Houtum (note 32) p. 56 and Zimmerbauer (note 32).

78. O. Sykes and D. Shaw, 'Investigating Territorial Positioning by Sub-State Territories in Europe', Regional \& Federal Studies 18/1 (2008) p. 55.

79. F. Barca, An Agenda for a Reformed Cohesion Policy, independent report prepared at the request of Danuta Hübner, Commissioner for Regional Policy, available at $<$ http://ec.europa.eu/regional_policy/archive/policy/future/barca_en.htm>.

80. Article 7(2), modified by European Council and European Parliament, 'Regulation (EU) No. 1302/2013' (note 12).

81. Non-approval of the EGTC has to be justified and the member state's decision has to be taken within six months; ibid., section $5 \mathrm{a}$.

82. Levrat (note 14) and Committee of the Regions, EGTC Monitoring Report 2014 Implementing the Strategy Europe 2020 (written by Metis GmbH), 2014, p. 69, available at $<$ http://www.cor.europa.eu $>$.

83. M. Niedermeyer and P. Moll, 'Saar-Lor-Lux - vom Montandreieck zur "Grossregion". Chancen und Möglichkeiten einer grenzüberschreitenden Regionalpolitik in Europa', in H.-P. Dörrenbächer, O. Kühne, and J.M. Wagner (eds.), 50 Jahre Saarland im Wandel (Saarbrücken: Institut für Landeskunde im Saarland 2007) pp. 298-299.

84. C. Schulz, 'Luxembourg dans la "Grande Région“', in P. Bousch, T. Chilla, O. Klein, P. Gerber, C. Schulz, C. Sohn, and D. Wiktorin (eds.), L'atlas du Luxembourg Luxemburg Atlas (Köln: Emons Verlag 2009).

85. M. Helfer, 'Die Industrialisierung der Großregion SaarLorLux', in C. Wille (ed.), Lebenswirklichkeiten und politische Konstruktionen in Grenzregionen - Das Beispiel der Großregion SaarLorLux: Wirtschaft - Politik - Alltag - Kultur (Bielefeld: Transcript 2015).

86. H.-P. Dörrenbächer, 'Ein grenzüberschreitender Wirtschaftsraum? Gemeinsame und individuelle Entwicklungen seit der Krise des Montansektors', in C. Wille (ed.), Lebenswirklichkeiten und politische Konstruktionen in Grenzregionen - Das Beispiel der Großregion SaarLorLux: Wirtschaft - Politik - Alltag - Kultur (Bielefeld: Transcript 2015).

87. ESPON and University of Luxembourg (note 29).

88. CESGR, Rapport sur la Situation Economique et Sociale de la Grande Région 2013/ 2014 pour le Comité Economique et Social de la Grande Région (Saarbrücken: Ministerium für Finanzen und Europa 2014) p. 47, available at <http://www.ibaoie.eu/fileadmin/user_upload/Berichte/WSAGR-Berichte/DE_FR_WSAGR-Bericht_ No5_2.pdf>.

89. $11^{\text {ème }}$ Sommet des Exécutifs de la Grande Région, Déclaration Commune (Luxembourg 2009).

90. Later referred to as "the Summit".

91. The other main institutions of cooperation are:

- CESGR (Economic and Social Council of the Greater Region) provides the Summit with regular advisory reports on the economic and social situation. A unique institution of its kind in Europe, it gathers representatives from chambers of commerce or industry and syndicates. 
- CPI (Interregional Council of Parliaments) gathers representatives of all parliaments and elected assemblies of the Greater Region, produces non-binding recommendations.

- EuRegio SaarLorLux+ gathers municipalities.

- Quattrople: city network between Luxembourg city, Metz, Saarbrücken and Trier.

- ToniCités: city network between Arlon, Esch s./Alzette, Longwy, Luxembourg city.

92. E. Evrard, Suprarègionalisation transfrontalière? Grande Règion SaarLorLux, 2013, $\mathrm{PhD}$ thesis, Luxembourg, available at <http://hdl.handle.net/10993/10459>

93. Church and Reid (note 9).

94. It will be replaced by another EGTC to manage the next INTERREG V A Greater Region programme; $14^{\text {ème }}$ Sommet des Exécutifs de la Grande Région, Déclaration Commune (Mainz 2014) p. 31. Since the members of the cooperation are almost the same in both EGTCs, it was envisaged to create only one EGTC responsible for both objectives. However, since they have objectives and sources of funding which do not completely overlap, it was decided to split them.

95. Evrard (note 92).

96. The empirical data for this article are drawn mainly from two research projects conducted in this region: the ESPON/Metroborder project (2009-2010) (note 29), during which around twenty expert interviews and a Delphi study were conducted, and a PhD project (2009-2013), during which another ten interviews were conducted.

97. Perkmann (note 5).

98. The EGTC INTERREG IV A will be shortly replaced by a newly created EGTC to conduct the INTERREG VA programme.

99. Arrêté grand-ducal du 30 juillet 2013 autorisant la création du Groupement européen de Coopération territoriale (GECT) "Secrétariat du Sommet de la Grande Région” (note b, under Table 2), art. 15 and 18 (2).

100. Ibid.

101. R. Belkacem and I. Pigeron-Piroth, 'Un Marché de l'Emploi Intégré? L'Emploi Frontalier et ses Dimensions Socioéconomiques',in C. Wille (ed.), Lebenswirklichkeiten und politische Konstruktionen in Grenzregionen - Das Beispiel der Großregion SaarLorLux: Wirtschaft - Politik - Alltag - Kultur (Bielefeld: Transcript 2015) pp. 39-60.

102. C. Wille, 'Grenzüberschreitende Alltagspraktiken in der Großregion SaarLorLux: eine Bestandsaufnahme', in C. Wille (ed.), (ed.), Lebenswirklichkeiten und politische Konstruktionen in Grenzregionen - Das Beispiel der Großregion SaarLorLux: Wirtschaft - Politik - Alltag - Kultur (Bielefeld: Transcript 2015) pp. 133-156.

103. A. Schönwald, 'Alle an einem Strang? Zur Rolle der Identitäten und Stereotypen in der grenzüberschreitenden Kooperation, C. Wille (ed.), (ed.), Lebenswirklichkeiten und politische Konstruktionen in Grenzregionen - Das Beispiel der Großregion SaarLorLux: Wirtschaft - Politik - Alltag - Kultur (Bielefeld: Transcript 2015) pp. 107-130.

104. Paasi (note 27). 